


\section{ODNOSI S JAVNOŠĆU I}

\section{DIGITALNO OGLAŠAVANJE}

PUBLIC RELATIONS AND

DIGITAL ADVERTISING 


\title{
THE DIGITAL ADVERTISING GAP AND THE ONLINE NEWS INDUSTRY IN CROATIA
}

\author{
Paško Bilić :: Jaka Primorac
}

IZVORNI ZNANSTVENI RAD / DOI: 10.20901/ms.9.18.4 / PRIMLJENO: 17.07.2018.

\begin{abstract}
Internet advertising brought about many changes in communication production, distribution, and consumption. By using critical political economy of communication as the mainstay of our approach, we provide supporting evidence of the ambiguous influence of data-driven advertising dynamic on the news industry and audience habits. We look at what we define as the digital advertising gap, or the difference between the size of the internet advertising market and the total income of digital news' firms. Digital intermediaries such as Google and Facebook are the final destinations for the majority of internet advertising investments in Europe and Croatia. A multi-sided, internet advertising market creates a fertile ground for the production of untrustworthy journalistic content. The digital advertising gap provides an example of a 'market failure' in which the market does not efficiently allocate public information goods. We argue that the confidence in the ability of the market to self-regulate the internet should be re-considered in European and national media policies.
\end{abstract}

\section{KEYWORDS}

INTERNET ADVERTISING, DIGITAL INTERMEDIARIES, NEWS INDUSTRY, MARKET FAILURE, POLICY FAILURE, PUBLIC GOODS, JOURNALISM

Authors note

Paško Bilić :: Institute for Development and International Relations, Department for Culture and Communication, Zagreb, Croatia :: pasko@irmo.hr

Jaka Primorac :: Institute for Development and International Relations, Department for Culture and Communication, Zagreb, Croatia :: jaka@irmo.hr 


\section{INTRODUCTION}

Placing advertisements alongside print, radio and television communications was the key strategy for reaching potential consumers and selling products. In the digital era, reaching consumers has become highly complex due to the availability of digital intermediaries offering access to massive databases of consumer data. New advertising dynamics include predictive analytics, programmatic advertising, native advertising, content personalization, etc. Firms such as Google and Facebook are at the forefront of these data-driven developments. They do not produce content, but serve as intermediaries and distribution channels for news and advertising. The widespread usage of intermediary platforms created what Joseph Turow (2011) calls the 'new advertising food chain'. Algorithms and other automated solutions allow agencies to reach individuals in real time on whatever pages they land on the internet. This decoupling of audiences from context, Turow (2011: 69) argues, marks a historic shift in deciding what content to support through advertising placement. Media content and context are no longer the primary factors determining advertising placement. Internet advertising investments are on the rise but instead of being distributed between different news media firms they end up being captured by two major firms: Google and Facebook.

Recent studies have shown that digital news is heavily accessed via intermediaries acting as distribution channels for online content (Reuters Institute, 2018). The most visited digital intermediaries such as Google and Facebook rely heavily on internet advertising as their main source of revenue. A total of $86 \%$ of Alphabet Inc.'s (the firm that owns Google) \$110.855 billion worldwide revenue in 2017 was from advertising (Alphabet Inc., 2018). In the same year, Facebook recorded a $\$ 40.65$ billion revenue with $98 \%$ coming from advertising (Facebook, 2018). News organizations lack the comparable financial and technical resources to harness network effects and to establish stable revenue streams through similar economies of scale. Language barriers and specialized editorial policies make it impossible to reach the scale of operations comparable to Google and Facebook. Moreover, other potential sources of revenue such as subscription or donations are difficult to establish in the face of well-known internet users' habits for free access to digital content.

Automated software systems deployed by digital intermediaries provide them with efficient and streamlined connections with internet users and consumers. The capacity for displaying content to specific users based on their social media usage, search history, location, and other data proxies has led to many controversies over their gatekeeping power (Tambini and Labo, 2016). Major concerns include monopolistic behaviour, surveillance, bias, distribution of 'fake news', etc. Control over the distribution of resources by digital intermediaries is the key to understanding the loss of revenue for journalism, poor sustainability of news industries, and the impact of these conditions on democracy (Couldry and Turow, 2014). One of the burning questions for contemporary societies is how the new configuration of actors and power relations affects the public sphere. The accompanying normative question is how the balance between commercial and public interests should be (re-)negotiated and institutionalised. 
Changes in contemporary communicative structures require a deeper analysis of the complex relation between market mechanisms and democratic processes. The news industries produce public goods which cannot be consumed through use (Garnham, 1986; Doyle, 2002). In this paper, we will argue for the need to take into account the underlying economic processes of changes in advertising dynamics in order to connect them with changes in the digital news industry and user habits. Our theoretical position differs from a purely economic analysis and looks, instead, at how the underlying structural conditions in advertising dynamics influence the news industry in terms of its democratic role of informing citizenry (Baker, 1992; Golding and Murdock, 1979; Hardy, 2014; McChesney, 2013; Pickard, 2013, 2016). In particular, we look at opportunities and/or structural constraints for news industries in the production of public information goods (Murdock and Golding, 2016).

In the first section, we will discuss the complex advertising markets in the context of digital media. The second section briefly introduces the concept of market failure which provides an analytical starting point towards defending public goods on the internet. In the third section we will discuss the methodological approach to estimating market failures in the internet advertising markets. We will present the market shares of Google and Facebook and discuss the use of different data sources for an adequate assessment of digital advertising markets. The fourth section will present the European dimension of advertising revenue capture by Google and Facebook and the habits of accessing digital news. The fifth section deals with the Croatian case and outlines an estimate of the impact of digital intermediaries on news industries by looking at the level of the internet advertising investments; the income of digital news media; commercial influence over editorial content; and the perception of the quality of digital news content and citizens' trust in digital news media. The sixth section briefly discusses future research directions. In the concluding section we tie all the arguments together and provide preliminary policy recommendations.

\section{MARKETS, ADVERTISING AND DIGITAL INTERMEDIARES}

Defining the terms market and market economy is no easy task. In purely economic terms the market economy presupposes supply and demand of goods and services in competitive markets. Goods and services are produced and purchased on the basis of rational decisions by actors with interests in entering market exchanges. Markets coordinate rational decisions between consumers, firms, and governments (Doyle, 2002: 4). Yet economic transactions cannot be separated from social contexts influencing the quality and intensity of exchanges. Karppinen and Moe (2014: 328) argue that the term 'market' is a highly contested concept in media policy research. They identify two main distinct meanings of the term. The first is concerned with markets as concrete, empirically observable institutions. This approach is certainly not without major problems and pitfalls. The second is a metaphorical meaning which refers to a more abstract conception of the 'market logic'. In the second meaning, authors argue, the market can be understood as a 
framework for discussing various aspects of culture and society. It is in this metaphoric sense that we can discuss the politically contested nature of the market.

Markets are deeply entangled with the media as key institutions in the development of modern societies (Murdock, 1993). The mass media played a role of establishing a field of common understanding among citizens. Advertising was an important strategy for reaching consumers and boosting sales. In media economics, advertising is defined as a form of competitive behaviour as firms use advertising to compete in enticing consumers to switch to their own product rather than that of their rivals (Doyle, 2002: 41). In pre-digital and pre-cable TV times the publishers were able to control access to wider audiences and to set the prices of advertising (Couldry and Turow, 2014). As the media started to differentiate, channels multiplied, and audiences segmented (Katz, 1996) to the point when the media markets started crumbling. The commercialisation of the World Wide Web in the nineties, accompanied by the rise of internet penetration levels, accelerated the trend towards weakening the ability of traditional media to attract advertising. Digital intermediaries established entirely new types of advertising markets, heavily reliant on data capture and processing. Traditional, mass media markets, according to Karppinen and Moe (2014: 331), were two-sided markets as they sold products to consumers on the one hand, and audiences to advertisers on the other hand. In addition to facilitating such transactions, digital intermediaries engage in the collection and commodification of data traces created by internet users. For this reason, internet advertising markets, in which digital intermediaries play a crucial role, are considered three-sided, or multi-sided, markets (Karppinen and Moe, 2014; Mansell, 2015a; Tambini and Labo, 2016).

Massive data processing, analysis and packaging have resulted in new ways of targeting potential consumers through advertising placement. The practice of collecting cookies, data from login registration, and tracking pixels has been ongoing for some time. According to Turow (2017) such type of data is called first party data. Second party data, on the other hand, is data about individual app or website visitors provided to advertisers. Third party data denotes information collected by firms specialised in audience tracking and targeted advertising. Linking these data sources together has created an advertising industry increasingly reliant on so-called predictive analytics about individuals most likely to purchase specific products and services (Turow, 2017: 12). In the second decade of the twenty-first century, Turow explains, programmatic advertising took hold. This type of advertising allows individual digital publishers to sell website and app space where they are competing with one another in order to sell targeted advertising to specific sociodemographic groups. In addition to predictive analytics and programmatic advertising, new trends include advertising personalization and native advertising in which the line between editorial journalistic content and advertising is blurred.

While they might seem rational from a purely economic perspective, internet advertising practices create multiple negative externalities in contemporary society. For example, Jason Pridmore and Detlev Zwick (2014) warn that in the digital realm there is a change in speed and degree to which firms are able to collect, sort, and process information 
about consumers through surveillance practices. Unregulated practices of the advertising industry, blurring between native advertising and editorial content, increasing surveillance and other issues demand a revised debate about media independence (Karppinen and Moe, 2016). In this sense, a perspective grounded in media economics (Doyle, 2002; Alexander et al., 2004) focusing solely on the structure of market, competition mechanisms, and market equilibrium will not suffice. In contrast, the critical political economy perspective challenges the sole focus on markets and argues that the value of market-based exchanges in creating public and social value is limited (Hardy, 2014; Mosco, 2009).

\section{MARKET FAILURE AS A POLICY FAILURE}

The concept of market failure goes beyond the market as the most efficient and desirable means for allocating important resources such as public goods, information and knowledge. It was defined by Bator (1958: 351) as the failure of a more or less idealized system of price-market institutions to sustain 'desirable' activities and to stop 'undesirable' activities. By relying on Bator's concept of market failure, Pickard $(2013,2016)$ argues that journalism, understood as a public good serving the public good creates positive externalities such as increased knowledge and an informed populace. Inability to take such a stance in defence of public goods leads, according to Pickard $(2013,2016)$, to policy failures. Market competition for advertising revenues between digital intermediaries and news industries results in market dominance of Google and Facebook (Figure 1), a clear example of 'market failure'.

The argument that news industries cannot perform their democratic role due to the loss of advertising revenues runs counter to the critical media studies and political economy traditions (Baker, 1992; Golding and Murdock, 1979; Faraone, 2011; Hardy, 2014). Critical media studies argued that advertising is detrimental to the performance of independent journalism and promotion of professional journalistic norms. Advertising leads to commodification and commercialisation of media cultures and the public sphere. With regard to the printed press, Baker (1992) argued that, although advertising pays most of the costs and makes the media widely available, it also represents a threat to a free and democratic press. The contemporary digital media system and the specific configuration of actors involved in content production, distribution, and consumption clearly shows that advertising is rapidly moving away from news and media industries as their 'natural allies'.

\section{ADVERTISING AND THE ONLINE NEWS INDUSTRY DATA: A METHODOLOGICAL NOTE}

The empirical sections of the paper build on multiple data sources in order to discuss structural conditions in which the Croatian digital news industry operates. The first step was to provide information on the shares of digital intermediaries in European markets. However, internet advertising reports (Pricewaterhouse Coopers) do not disclose the 
shares by individual firms. To provide estimates we used the methodology developed by Winseck (2017) in the Canadian Media Concentration Research Project. ' The main sources used for these calculations include audited market reports for Google and Facebook (Security and Exchange Commission's fillings Form 10-K), Pricewaterhouse Coopers IAB ADEX benchmark reports $(2016,2017)$ for the sizes of the internet advertising markets and internet advertising per capita, Internet Live Stats for the sizes of respective internet populations, and Statista for Facebook users per country.

The second step was to determine recent trends in advertising dynamics in Croatia. Advertising investments are reported nationally on a yearly basis by the Croatian Association of Communications Agencies (HURA) - the industry association in the market communications sector. HURA reports on the so-called Media AdEx (Advertising Expenditure) which relates to buying media space. It is an assessment of investments in advertising among main TV stations, larger print editions and their online editions, radio, billboards and internet advertising in general. The data relates to net investments in buying media space. The assessment is based on audience reach (AGB Nielsen, Ipsos) and financial indicators from the main financial agency (FINA) and HURA member agencies for market communication (HURA, 2018).

The third step was to determine the commercial income for Croatian news media websites. Edited websites are defined as electronic publications in Article 2 of the Electronic Media Act (OG 153/09). In accordance with the Act, all electronic publications participate in financing the Agency for Electronic Media with $0.5 \%$ of their yearly gross income from the electronic publications services in the previous fiscal year. Based on these legal requirements we determined the total commercial income of registered digital news websites in Croatia. In the annual financial reports they file to the financial agency (FINA) it is not possible to discern how much of their income relates to electronic publications' services. Most of them engage in multiple media activities (e.g. online, print, television) (see Figure 3) so the income from electronic publication services is not reported as a separate revenue stream. Therefore, the Agency for Electronic Media is the only body keeping track of the websites' income. In addition to regulatory data, we also used audience surveys conducted by the European Commission (2018), Eurobarometer (2016), and Oxford's Digital News Report (2018).

\section{ADVERTISING REVENUE CAPTURE AND ACCES TO DIGITAL NEWS: THE EUROPEAN DIMENSION}

Firms offering web search services, social networking, e-commerce, cloud services, distribution channels for apps, and other digital services have come to dominate the

\footnotetext{
$\overline{1}$ One of the factors determining the share by Google in Canada was the size of the Canadian population in relation to the population of the United States. This is justified since Canada and the US have roughly the same level of internet penetration. Applying this factor to determine shares in European countries proved highly skewed shares due to differences in internet penetration levels. For example, the US penetration is above $90 \%$ while in countries such as Croatia it is closer to $70 \%$. Instead of using the population factor we used the internet population as part of the US internet population factor to calculate the share for Google.
} 
global internet. The success of technological firms is predicated on extracting data as a resource for the development of platform-based business models (Srnicek, 2017). Changes in their products and services effectively structure, re-shuffle and re-organize the habits and preferences of global internet users. In order to economically valorise data, digital intermediary firms invest in attracting, and retaining, ever higher numbers of internet users. The ultimate resource for economic valorisation of data are algorithms. These technical artefacts shape digital media production and consumption in many ways (Helberger, 2016; Napoli, 2014), ultimately creating an automated public sphere (Pasquale, 2017). Market control over internet advertising markets results in infrastructural, rulesetting power of digital intermediaries. Firms such as Google and Facebook position themselves as multi-sided platforms that facilitate interactions between providers and consumers of online information (Tambini and Labo, 2016). In other words, they facilitate interactions between economic agents for their own economic benefit (Mansell, 2015a), which strengthens their position, and creates monopolistic control over advertising markets.

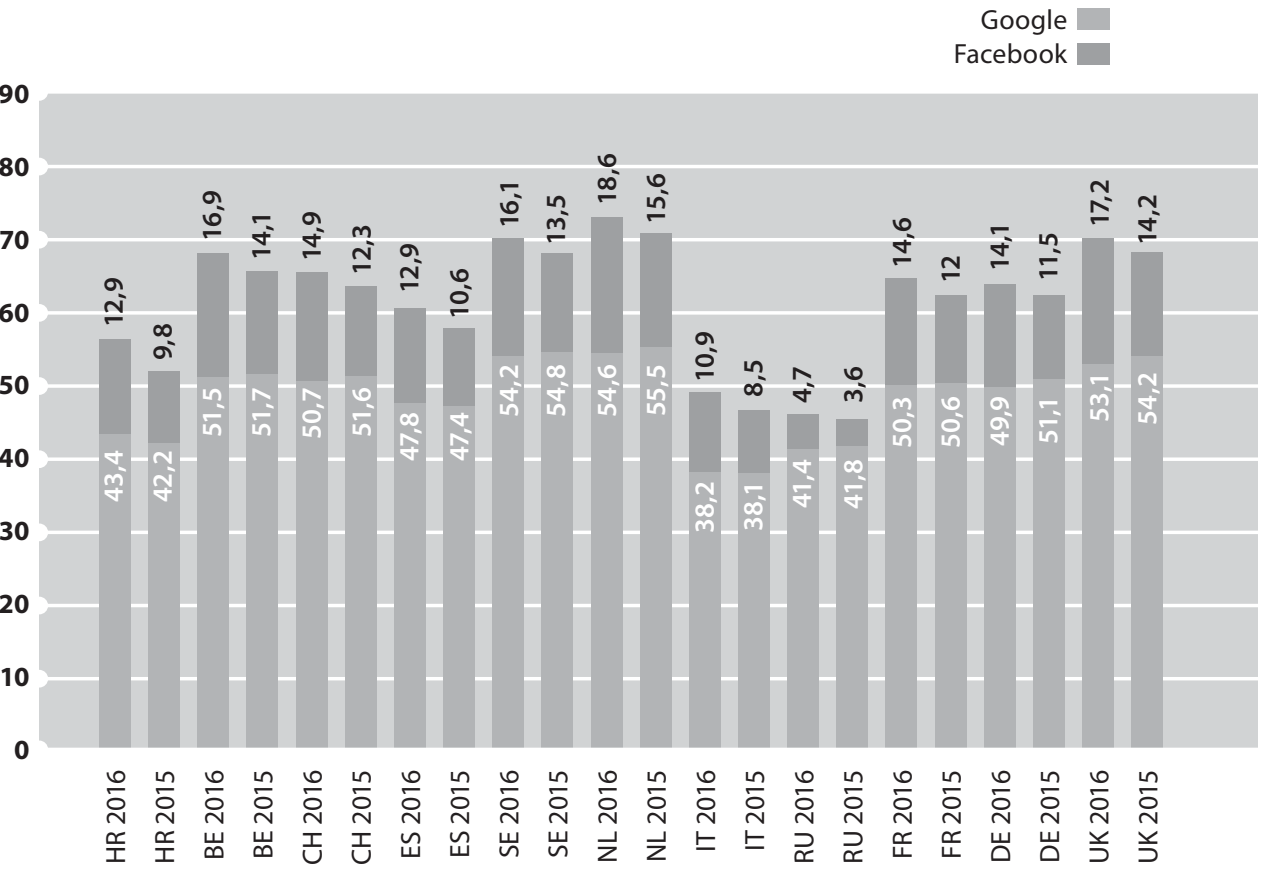

Figure 1. 
Figure 1 shows the calculated estimate of the internet advertising shares by Google and Facebook in ten biggest European markets (total size) including Croatia in 2015 and 2016. The exact shares depend on the revenues generated in the US and Europe, the size of respective internet populations, number of Facebook users, and respective internet advertising per capita. For more developed countries in terms of internet advertising per capita - such as the UK, Sweden and the Netherlands - the shares of Google and Facebook tend to be higher. In countries with less internet advertising per capita and smaller internet penetration levels - such as Russia and Italy - Google and Facebook tend to have smaller shares. In 2016 the shares record a slight yearly growth in all countries. In Croatia, Google captured $43.4 \%$ and Facebook $12.9 \%$ of the online advertising market in 2016 . A dominating market share in internet advertising markets should be contextualised in light of the internet users' habits with regard to accessing digital news. Recent studies (Reuters Institute, 2018) conducted in 37 countries worldwide ${ }^{2}$ show that internet users prefer to access news content directly on the news websites (32\%), through search (24\%), social media (23\%), email (6\%), mobile alerts (6\%), and aggregators (6\%). Put differently, the majority of internet users (65\%) in the selected sample prefer to access news content through side-door access, mostly via digital intermediaries such as Google and Facebook (Reuters Institute, 2018).

Avoiding direct access to news content creates economic sustainability problems for news organizations and their ability to attract and sustain advertising revenues. A different study conducted in Croatia shows a similar trend in user preferences (Bilić et al., 2017). It shows that the majority of internet users in Croatia prefer to access news content through search engines (52.9\%), direct access (45\%) and Facebook (41.9\%). Direct access to news websites is important because the main pages are the pages where the highest numbers of potential readers/consumer land. News websites cannot achieve a sufficient economy of scale to attract advertisers since the audience reach of even the most-read news websites is dwarfed in comparison to the scale of Google's operations. Alternative revenues in the form of subscription are sometimes referred to as the potential way to move the industry forward. However, according to existing Croatian surveys, only $16.4 \%$ of internet users pay for content on the internet. ${ }^{3}$ Simultaneously, $66.9 \%$ said they would not pay for content of the news portals they visit and only $6.8 \%$ expressed willingness to pay for such content (Bilić et al., 2017).

Based on such figures it is necessary to discuss connections between advertising revenue capture by digital intermediaries, the quality of public goods the local news industries are able, or unable, to produce, and changing habits of internet users. The capture of advertising investments and the accompanying transformations of the news industry are sometimes discussed in the context of Schumpeter's trope of 'creative destruction' (Schlesinger and Doyle, 2015). Such an approach views the destruction of news industries as a natural result of competitive markets. However, the markets also produce negative externalities on social processes and are, therefore, insufficient for securing long-term and

\footnotetext{
$\overline{2}$ Argentina, Australia, Austria, Brazil, Belgium, Bulgaria, Canada, Chile, Croatia, Czech Republic, Denmark, Finland, France, Germany, Greece, Hong Kong, Hungary, Italy, Ireland, Japan, Malaysia, Mexico, Netherlands, Norway, Poland, Portugal, Romania, Singapore, Slovakia, South Korea, Spain, Sweden, Switzerland, Taiwan, Turkey, UK and US.

${ }^{3}$ This includes all types of content including news, online games, etc.
} 
viable democratic solutions. In light of the evident decline of the societal importance of news industries, there is no clear response in terms of policy or regulatory initiatives for providing democratic visions for news industries in the digital age. The position in which the news industry finds itself in leads towards three socially troubling directions according to Turow (2011: 87): firstly, they are under pressure to pursue the kind of personalisation toward useful targets or waste that database-driven media buyers demand; secondly, they are forced to create privacy policies to hide particulars of buyers' audience-tracking and targeting activities from visitors to their sites; and thirdly, they further retreat from longtime professional journalistic norms in the interest of packaging personalized advertising with personalized soft news entertainment. It is to the third dimension that we turn our attention to in the following sections.

\section{STRUCTURAL CONDITIONS OF THE CROATIAN ONLINE NEWS INDUSTRY}

An unregulated digital media market is unable to ensure democratic outcomes in the face of competition with globally dominant digital intermediaries. There are few winners and many losers in this digital equation. For regulation to be successful in re-defining the democratic role of digital news media it needs to have a strong evidence base on which to act (Mansell, 2015a, 2015b). One way to move the discussion forward is to connect economic indicators with indicators evaluating digital journalism and news content as public goods performing a democratic role. According to recent EU-28 data, $91.4 \%$ of internet users in Croatia have read or downloaded digital news (and magazines) in 2017 as one of their main online activities. Such a widespread habit among internet users was ranked second in the EU, behind Lithuania. The EU-28 average is $72.5 \% .{ }^{4}$ Yet the fact that citizens read online news does not explain much about what kind of news they read, and what their perceptions of the news are. Also, it does not give sufficient information on how news is accessed and whether it offers a diversity of views and opinions. The role of digital intermediaries is crucial here as it frames the local revenue streams and structures user habits in accessing news. We propose to assess the structural constraints imposed by digital intermediaries on news industries by looking at four key dimensions: (1) internet advertising investments; (2) income of digital news media (i.e. electronic publications); (3) journalistic profession and commercial influence over editorial content; (4) perception of the quality and citizens' trust in digital news media.

\section{Internet advertising investments}

Based on existing advertising industry data, Figure 2 shows that total advertising investments in Croatia increased only slightly between 2015 and 2017. Television still captures the majority of investments (741 million HRK) although the market tends to be stagnant. The internet is continuously rising and in 2017 it overtook print as the second most used medium for buying advertising space. Advertising investments on the internet increased from 168 million HRK (Croatian Kuna) in 2015 to 245 million HRK in 2017.

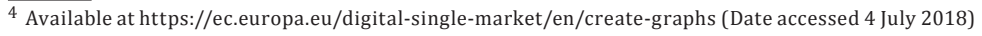


Between 2008 and 2017 they increased by more than eight times. In the same period, print advertising dropped by almost four times. More precise numbers on how much of the internet advertising investment relates to local firms, and how much of it relates to digital intermediaries such as Google and Facebook is unavailable in the data published by HURA. The figures on the continuous rise of internet advertising can be misleading if we do not take into account the market shares of Google and Facebook. As previously shown in Figure 1, Google and Facebook together captured $56.3 \%$ of the internet advertising market in Croatia in 2016.

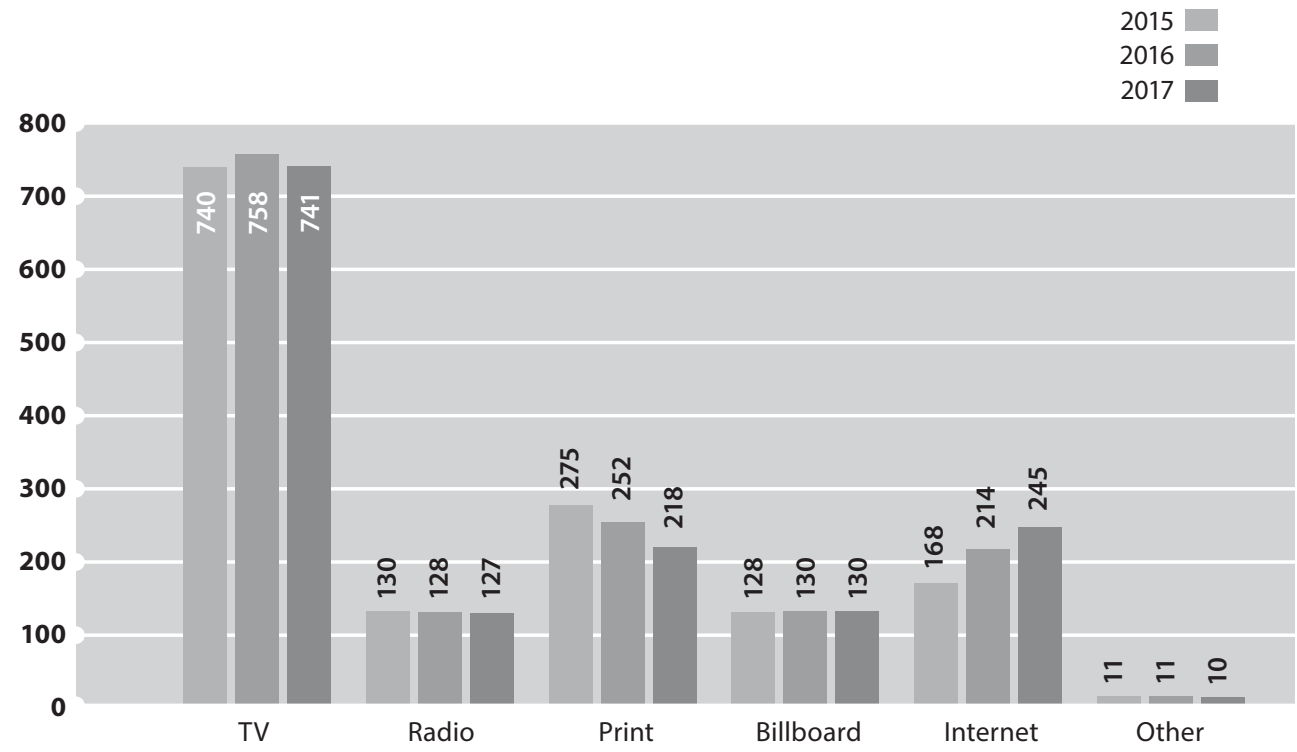

A Figure 2.

Media AdEx 2015-2017

Source: HURA (authors' analysis)

It is important to note that even in the most developed markets in terms of size and internet advertising per capita such as the United States it took a lot of time for internet advertising to surpass advertising on traditional media. For example, in 2010 internet advertising in the United States surpassed newspapers. But it was only in 2016 that internet advertising surpassed television in the United States to become the primary medium for advertising placement. In 2016 internet advertising recorded a total value of $\$ 72.5$ billion compared to $\$ 72$ billion for the television advertising market. 


\section{Digital news' (i.e. electronic publications') income}

The data for 2015 published by Bilić et al. (2017) showed that the total income for all 261 electronic publications registered at the time was 112.47 million HRK. Within that amount 3.43 million related to non-profit publications. All of the income for non-profit publications was from public funds in Croatia and/or international funds. Non-profit media have a legal obligation to channel all their income and profit to the development of their publishing activity. Total gross income from the commercial activity of electronic publications in Croatia in 2015 was 109.04 million HRK, much less than the internet advertising investments in the same year which were reported at a net worth of 168 million HRK by HURA. In Figure 3 it is also visible that the majority of income from electronic publications' activities (52.5\%) relates to firms whose primary media activity is in print. Firms whose online activity is their only media activity take up only $27.3 \%$ of income generated in 2015. They are followed by firms whose main activity is providing internet services, television and radio.
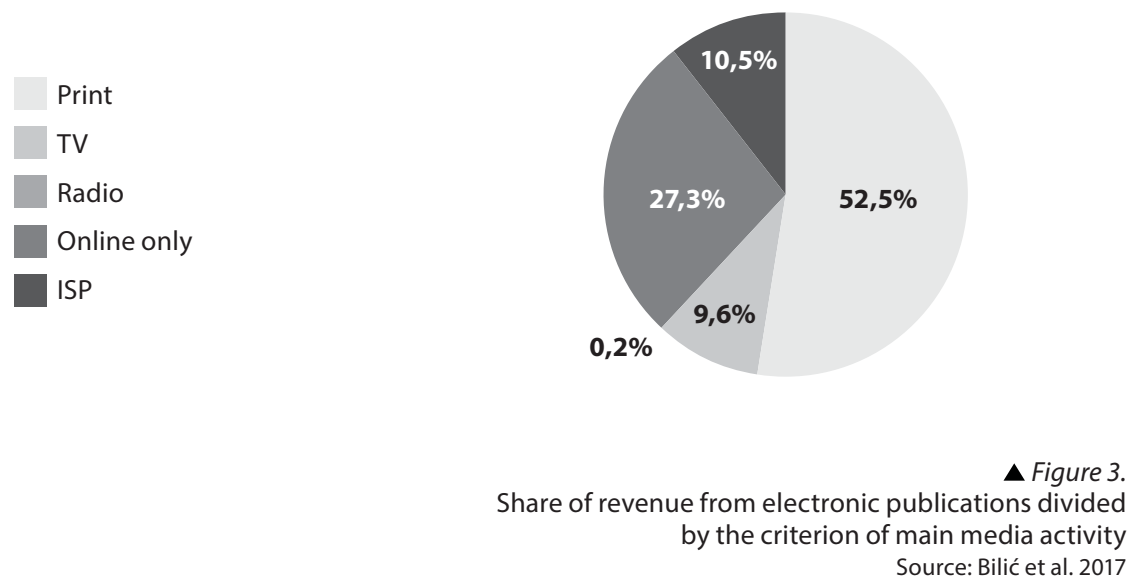

Figure 3 shows that traditional media are searching for publishing venues and sources of income in the internet advertising market. The unstable revenue, unexpected operational results, and potential losses generated in the internet market can be more easily covered for firms whose main business activity is providing other goods and services. For example, some of the firms providing internet services (ISP), as is the case with the Croatian Telekom which is majority-owned by Deutsche Telekom, also provide one of the most popular news websites in the country (T-portal).

If we look at the top electronic publications in terms of their share in the total recorded income for all commercial firms, we see that the market tends to be concentrated at the top. The top four firms in terms of gross income recorded $46.3 \%$ of the total income. The firms ranked between fifth and tenth place recoded $36.7 \%$. All of the other firms offering electronic publication services recorded $17 \%$ of the total recorded income. 
1.-4.

5.-10.

11.-20.

Other

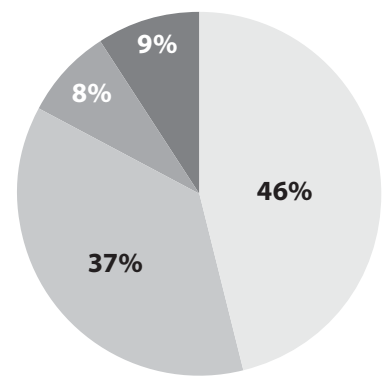

Figure 4.

Top 4 concentration

Source: Bilić et al. 2017

\section{Advertising and the journalistic profession}

Advertising often comprises between 60 and $80 \%$ of revenues for print media, according to Baker (1992). He argued that such dependence encourages the media to tailor their content in four different ways. First, the media tend to treat advertisers' interests charitably in their reports. Second, the media create a buying mood for more favourable reactions to advertisements. Third, the media try to make their content less partisan and less controversial to avoid offending advertisers' potential customers. Finally, the media tend to favour particular audiences with greater purchasing power. The internet erodes some of the news production costs and reconfigures the relationship between news industries and advertisers. In particular, internet reduces distribution and market entry costs. Yet, as Hardy (2014: 121) argues, the majority of the costs remain, in particular labour costs to produce high-quality news coverage, which represent two thirds of production costs. McChesney (2013) also argues that the internet does not alleviate the tensions between commercialism and journalism; it magnifies them. He discusses a widespread trend of underpaid or unpaid labour which pushes the reporting style towards topics that are 'easy and fun'.

The poor state of journalistic profession, heavy commercial influence over editorial content and editorial autonomy are some of the high risk areas for media pluralism in Croatia (Bilić et al., 2018). Particularly problematic areas include inefficient self-regulation, precarious labour conditions based on short-term contracts and deteriorating working circumstances, less time for investigative journalism, ownership and political pressure, etc. Simply looking at the output of digital outlets in times of important social events there is a noticeable lack of content diversity. For example, during the collection of signatures for the start of a referendum about the management of public infrastructure in late 2014, digital editorial boards showed a significant level of polarization. Editorial views of some of the most visited, commercial websites in the country were aligned with the political leaning of ownership (Bilić and Balabanić, 2016). At the same time, recent research shows that non-profit media provide alternatives to content produced by commercial and public 
service media (Bilić et al., 2018). Comparable research by Vozab et al., (2017) shows that $26 \%$ of internet users follow non-profit media. It also showed that the non-profit media audience has a higher political interest, political efficacy, is better-informed, and engages more in politics.

The importance of such research results lies in the fact that we need more nuanced understandings of digital environments. The digital news' space is highly complex. Apart from a large number of commercial firms, there is a large number of community (nonprofit media) as well as the traditional public service broadcaster extending its reach to the internet. The commercial media suffer more intensely than other media from some of the well-known problems of commodification and dependence of journalism on commercial decisions by editorial boards, management, and ownership. Competition with digital intermediaries is an additional issue to deal with in the long list of constraints for producing public information goods. Alternative media content is already available in the public service media and the third (non-profit) media sector. However, such public spaces can only be supported through policy initiatives that react to the existing digital market failures and promote public goods in digital environments. Unfortunately, the commercial logic is often used as an assessment of the role of public service and nonprofit media. Economic and competitive grounds have often been used as the dominant tools driving media policies in Europe. This is particularly emphasised in the context of state aid rules for supporting public services which are interpreted as distortions of the market (Bardoel and Vochteloo, 2012; Donders and Pauwels, 2008).

\section{Perception of digital news quality and trust in the media}

Recent studies on the state of the digital news market in Croatia (Bilić et al., 2017) have shown that among the main advantages of digital news Croatian internet users chose the reporting speed, interactivity of video, audio and textual material, the option to comment on the news content, and the option to connect and communicate with other users. Much of these advantages essentially relate to technical affordances of digital media, networking and sharing options for distributing and commenting news content, particularly through Facebook. Only eleven \% of the users see factual and reliable information as an advantage of digital news. The main perceived disadvantages of digital news were sensationalist reporting, too many advertisements, news without deeper analysis, and unchecked and untrustworthy information. The majority of negative perceptions of digital news relate to the perception of low journalistic standards and poor quality content. Comparable EU-wide data shows that a slight majority of the respondents (53\%) agrees their national media (print, television, radio, and internet) provide trustworthy information, while 44\% think it does not (Eurobarometer, 2016). According to the same study, less than half (47\%) of Croatian citizens agree that the national media provide trustworthy information. Looking at digital news only, $60.6 \%$ of Croatian internet users do not trust the information published on Croatian digital news media (Bilić et al., 2017). Such numbers are somewhat contradictory to the previously mentioned information that Croatian internet users are among the leaders in terms of reading and/or downloading online news in Europe. Internet usage habits point to the fact that digital journalism and online content are accessed, consumed, shared and discussed in other digital spaces - mostly those digital 
spaces offered by digital intermediaries such as web search and social networking. The data on high levels of mistrust in digital news also points to a disconnection between digital journalistic production on the one hand, and habits, routines and preferences of digital news consumption on the other hand.

\section{FUTURE RESEARCH}

Future research might take the form of at least three different directions. First, the empirical material in this study is limited by data gathering and reporting practices of existing industry and regulatory reports. The market shares for Google and Facebook are based on a calculated estimate and should not be viewed as exact figures on country specific revenues. Nonetheless, these estimates are based on widely accepted industry standards, as well as ongoing academic research (Winseck, 2017). If possible, future research should look for different ways of confirming and/or disputing these estimates. Second, audience data relies on secondary survey data and descriptive statistics of rudimentary statistical value. The survey data could be made more sophisticated by using tested and reliable scales for measuring well-studied phenomena such as trust in the media. However, it should also be noted that the continuously changing structural conditions of the digital news media will likely require new survey instruments and questionnaires more adapted to the complex interrelations between digital intermediaries, digital news media and their audiences. Developing new scales and using them in relation to economic variables could prove to be a fruitful research direction in the future. Finally, the Croatian digital news industry and national internet advertising market are undeveloped compared to the global leaders such as the United States and the United Kingdom. In these countries there is a widespread public outcry for more regulation of technology giants. This should be viewed as a warning sign for countries such as Croatia in which there is no clear sense of direction in developing digital media policies (Bilić and ŠvobĐokić, 2016). Experiences from the US and the UK show that digital policies should be more attentive to the ways in which market-driven mechanisms have created instabilities in the complex relations between the internet, democracy, and citizens. A comparative, transnational research approach could be envisioned in which the advertising shares of Google and Facebook might be fruitfully compared with other country-specific digital news industry and audience habits' data. Ultimately, more precision should be aimed for in order to determine correlations between economic indicators, quality of news industry output and audience habits.

\section{CONCLUSION}

This paper attempted to discuss how digital intermediaries' advertising value extraction reflects on the digital news industry in Croatia. Google's and Facebook's business models are founded on capturing internet advertising investments on a global scale, which has structural implications for advertising markets worldwide. It would be fair to conclude that Google and Facebook do offer access to much of the content that would be difficult to find, 
or impossible to access. Yet as they establish themselves as market leaders and the main firms offering web search and social networking services, the drive for profit maximization stifles their ability to perform socially and democratically desirable actions. We argued that their main influence relates to the capture of internet advertising investments which undermines the capacity of news industries to produce public goods. In the debate about the impact of digital intermediaries on contemporary society, the systemic drainage of available resources from news industries needs to be addressed worldwide. Internet advertising in Croatia has increased eight times between 2008 and 2017. In 2015 total net investments in internet advertising were reported at 168 million HRK. In the same year, the gross commercial income from 261 registered news websites in Croatia was 109.94 million HRK. According to our estimates Google and Facebook captured 52\% of the internet advertising market in Croatia in 2015. Simultaneously, journalistic profession is suffering from many acute problems such as inefficient self-regulation, ownership and political pressure, precarious labour conditions based on short-term contracts and deteriorating working circumstances with less time for investigative journalism. Unsurprisingly, citizens perceive the main disadvantages of digital news in sensationalist reporting, advertising overload, news without deeper analysis, and untrustworthy information.

Digital news industries face the challenge of overcoming the advertising market control of Google and Facebook on the one hand, and overcoming internet user habits of accessing free content on the other hand. Democracy, in such a context, falls into a digital advertising gap between rising internet advertising markets, and the unsustainable income streams of digital news firms. Potential solutions include stronger support for public service and non-profit media which already provide alternatives to the marketdriven system. In order to prevent further deterioration of democratic standards of media pluralism, the European Union and the individual nation states need to take a stronger stance in promoting public goods in digital news environments in order to reclaim the broken relationship between journalists and their audiences. The fact that there is such a disconnect points to a market failure and the fact that un-regulated, or weakly regulated, markets are unable to provide public goods the citizens need. Citizens are exposed to a wide array of content on the internet, yet when it comes to news that content is unrelated to quality and trustworthy information. The way to remedy that in the face of drying revenue streams will likely continue to be the main problem for ensuring desired democratic outcomes in the digital age. In addition to seeking diversity of providers and types of content, preventing growth and abuse of monopolistic power in media and communications (Picard and Pickard, 2017), digital media pluralism should address the digital advertising gap, or the systemic drainage of available resources from news industries worldwide.

The European Commission has been highly active in challenging the monopolistic position of major technological firms. Google has been fined $€ 2.7$ billion for abusing its dominant position in 2017, and an additional $€ 4$.3 billion for abusing its market dominance in 2018. Yet the next step should be to closely connect economic issues of anti-trust regulation with political and democratic processes. The continued faith in the ability of the market to self-regulate the internet should be re-considered. There already exists a 
strong European tradition of supporting public service, community and non-profit media. A progressive media strategy should take these structural processes into account in order to rethink the role of existing market mechanisms and in order to create new conditions for balancing commercial and public service production. Such policy calls might seem outdated, especially in light of the fact that many public service broadcasters in Europe are suffering from internal institutional weaknesses and strong political interferences. However, new structural conditions of data-driven internet advertising markets have already established themselves as lucrative business models. In light of new discursive strategies of promoting artificial intelligence, as well as trends towards the convergence between cloud computing, big data analytics and the Internet of Things (Mosco, 2017) it is likely that data-driven business models will continue to expand. This can also be expected in peripheral countries such as Croatia where internet penetration levels are still relatively low and internet advertising per capita is among the lowest in Europe. To ensure that market failures do not lead to policy failures a renewed attention to the old issue of balancing public and commercial interest will remain the main challenge for future media policies and regulatory interventions.

\section{References}

>Alexander, Alison; Owers, James; Carveth, Rod; Hollifield, C. Ann and Greco, Albert N. (eds) (2004) Media Economics: Theory and Practice. Manwah, NJ: Lawrence Erlbaum Associates.

>Alphabet Inc. (2018) Form 10-K. https://www.sec.gov/Archives/edgar/ data/1652044/000165204418000007/goog10-kq42017.htm\#sC68A2AAB67BD8DF88FFA78DBABC38 20B (04/07/2018.).

>Baker, C. Edwin (1992) Advertising and a Democratic Press. University of Pennsylvania Law Review 140 (6): 2097-2243. DOI: 10.2307/3312414.

>Bator, Francis M. (1958) The Anatomy of Market Failure. The Quarterly Journal of Economics 72 (3): 351-379. DOI: 10.2307/1882231.

>Bilić, Paško and Balabanić, Ivan (2016) Pluralizam ili polarizacija masovnih medija u mrežnom prostoru: slučaj monetizacije hrvatskih autocesta. Revija za sociologiju 46 (2): 175-204. DOI: 10.5613/ rzs.46.2.3.

>Bilić, Paško and Švob-Đokić, Nada (2016) The Pendulum Model of Croatian Media Policy: Digitalisation between Public Interests and Market Competition. European Journal of Communication 31 (5): 503-518. DOI: 10.1177/0267323116659976.

>Bilić, Paško; Balabanić, Ivan; Primorac, Jaka; Jurlin, Krešo and Eterović, Ružica (2017) Analiza tržišta elektroničkih publikacija. AEM: Zagreb.

>Bilić, Paško; Furman, Ivo and Yildirim, Savas (2018) The Refugee Crisis in the Croatian Digital News: Towards a Computational Political Economy of Communication. Political Economy of Communication 6 (1): 59-82.

>Bilić, Paško, Petričušić, Antonija and Eterović, Ružica (2018) Media Pluralism Monitor 2017 Croatia Report. Centre for Media Pluralism and Media Freedom: Florence, Italy.

>Bardoel, Jo and Vochteloo, Marit (2012) Conditional access for public service broadcasting to new media platforms: EU state-aid policy vis-a-vis public service broadcasting - The Dutch case, pp. 303-315. in: Natascha Just and Manuel Puppis (eds) Trends in Communication Policy Research. Bristol, Chicago, IL: Intellect Ltd.

$>$ Couldry, Nick and Turow, Joseph (2014) Advertising, Big Data, and the Clearance of the Public Realm: Marketers' New Approaches to the Content Subsidy. International Journal of Communication 8: $1710-1726$. 
>Donders, Karen and Pauwels, Caroline (2008) Does EU policy challenge the digital future of public service broadcasting? An analysis of the commission's state aid approach to digitization and the public service remit of public broadcasting organizations. Convergence 14 (3): 295-311. DOI: $10.1177 / 1354856508091082$.

>Doyle, Gillian (2002) Understanding Media Economics. London, Thousand Oaks, New Delhi: SAGE Publications. DOI: 10.4135/9781446279960.

>Eurobarometer (2016) Special Eurobarometer 452: Media Pluralism and Democracy. https:// ec.europa.eu/digital-single-market/en/news/media-pluralism-and-democracy-specialeurobarometer-452 (04/07/2018.).

$>$ Facebook (2018) Form 10-K. https://www.sec.gov/Archives/edgar/ data/1326801/000132680118000009/fb-12312017x10k.htm (04/07/2018.).

$>$ Faraone, Roque (2011) Economy, Ideology and Advertising, pp. 187-205, in: Wasko, Janet; Murdock, Graham and Sousa, Helen (eds) A Handbook of the Political Economy of Communications. Chichester: Blackwell Publishing. DOI: 10.1002/9781444395402.ch9.

$>$ Garnham, Nicholas (1986/2006) Contribution to a Political Economy of Mass-Communication, pp. 201-229, in: Durham, Meenakshi Gigi and Kellner, Douglas (eds) Media and Cultural Studies: Key Works, Revised edition. Malden, USA; Oxford, UK; Victoria, Australia: Blackwell Publishing. $>$ Golding, Peter and Murdock, Graham (1979) Ideology and Mass Media, pp. 198-224, in Barett, Michelle; Corrigan, Philip; Kuhn, Anette and Wolff, Janet (eds) Ideology and cultural production. Beckenham: Croom Helm.

$>$ Hardy, Jonathan (2014) Critical Political Economy of the Media: An Introduction. London and New York: Routledge. DOI: 10.4324/9780203136225.

$>$ Helberger, Natali (2016) Policy Implications From Algorithmic Profiling and the Changing Relationship Between Newsreaders and the Media, Javnost - The Public 23: 2, 188-203. DOI: 10.1080/13183222.2016.1162989.

>HURA (2018) HURA Media AdEx medijska potrošnja. https://hura.hr/istrazivanja/medijskapotrosnja-u-hr/ (04/07/2018.).

>Karppinen, Kari and Moe, Hallvard (2014) What we Talk about When We Talk about 'The Market': Conceptual Contestation in Contemporary Media Policy Research. Journal of Information Policy 4: 327-341. DOI: 10.5325/jinfopoli.4.2014.0327.

>Karppinen, Kari and Moe, Hallvard (2016) What We Talk about When Talk about 'Media Independence'. Javnost - The Public 23 (2): 105-119. DOI: 10.1080/13183222.2016.1162986.

$>$ Katz, Elihu (1996) And Deliver us from Segmentation. Annals of the American Academy of Political and Social Science 546: 22-33. DOI: 10.1177/0002716296546001003.

$>$ Mansell, Robin (2015a) Platforms of Power. Intermedia 43 (1): 20-24.

$>$ Mansell, Robin (2015b) The Public's Interest in Intermediaries. Info: the Journal of Policy, Regulation and Strategy for Telecommunication, Information and Media 17 (6): 8-18. DOI: 10.1108/info-05-20150035.

>McChesney, Robert W. (2013) Digital Disconnect: How Capitalism is Turning the Internet Against Democracy. New York and London: The New Press.

$>$ Mosco, Vincent (2009) The Political Economy of Communication. London: SAGE Publications. DOI: $10.4135 / 9781446279946$.

>Mosco, Vincent (2017) Becoming Digital: Towards a Post-internet Society. Bingley, UK: Emerald Publishing. DOI: 10.1108/9781787432956.

$>$ Murdock, Graham (1993) Communications and the Constitution of Modernity. Media, Culture \& Society 15: 521-539. DOI: 10.1177/016344393015004002.

$>$ Murdock, Graham and Golding, Peter (2016) Political economy and media production: a reply to Dwyer. Media, Culture \& Society 38 (5), 763-769. DOI: 10.1177/0163443716655094.

$>$ Napoli, Philip M. (2014) Automated Media: An Institutional Theory Perspective on Algorithmic Media Production and Consumption. Communication Theory 24: 340-360. DOI: 10.1111/comt.12039. 
>Pasquale, Frank (2017) The Automated Public Sphere. University of Maryland Legal Studies Research Paper No. 2017-31. SSRN. https://papers.ssrn.com/sol3/papers.cfm?abstract_id=3067552 (04/07/2018.).

$>$ Picard, Robert G. and Pickard, Victor (2017) Essential Principles for Contemporary Media and Communications Policy Making. Reuters Institute for the Study of Journalism. University of Oxford. >Pickard, Victor (2013) Social Democracy or Corporate Libertarianism? Conflicting Media Policy Narratives in the Wake of Market Failure. Communication Theory 23: 336-355. DOI: 10.1111/ comt.12021.

>Pickard, Victor (2016) Confronting Market Failure: Past Lessons Toward Public Policy Interventions, pp. 127-142, in: Loyd, Mark and Friedland, Lewis A. (eds) The Communication Crisis in America and How to Fix It. New York: Palgrave Macmillan. DOI: 10.1057/978-1-349-94925-0_9.

>Pricewaterwhouse Coopers (2017) IAB Internet Advertising Revenue Report: 2016 Full Year Results. >Pricewaterwhouse Coopers (2017) IAB Europe ADEX Benchmark 2016: European Online Advertising Spend.

>Pricewaterwhouse Coopers (2016) IAB Europe ADEX Benchmark 2015: European Online Advertising Spend.

$>$ Pridmore, Jason and Zwick, Detlev (2014) Marketing and the Rise of Commercial Consumer Surveillance. Surveillance \& Society 8 (3): 269-277. DOI: 10.24908/ss.v8i3.4163.

$>$ Reuters Institute (2018) Digital News Report 2018. University of Oxford. http://www. digitalnewsreport.org/ (04/07/2018.).

>Schlesinger, Peter and Doyle, Gillian (2015) From Organizational Crisis to Multi-Platform Salvation? Creative Destruction and the Re-Composition of News Media Journalism 16 (3): 305-323. DOI: $10.1177 / 1464884914530223$.

>Srnicek, Nick (2017) Platform Capitalism. Polity Press.

$>$ Tambini, Damian, and Labo, Sharif (2016) Digital Intermediaries in the UK: Implications for News Plurality. Digital Policy, Regulation and Governance 18 (4): 33-58. DOI: 10.1108/info-12-2015-0056. >Turow, Joseph (2011) The Daily You: How the New Advertising Industry is Defining Your Identity and Your Worth. New Haven and London: Yale University Press.

>Turow, Joseph (2017) The Development of the Modern Advertising Industry, pp. 3-14, in: Hardy, Johnathan; Powell, Helen and MacRury, lain (eds) The Advertising Handbook. London and New York: Routledge. DOI: 10.4324/9781315558646-2.

$>$ Vozab, Dina; Peruško, Zrinjka and Čuvalo, Antonija (2017) Treći medijski sektor iz perspektive demokratski angažiranih publika [Third media sector from the perspective of democratically engaged audiences]. Politička misao, 54 (3): 108-132.

>Winseck, Dwayne (2017) Canadian Media Concentration Research Project. http://www.cmcrp.org/ (04/07/2018.). 


\section{DIGITALNI OGLAŠIVAČKI JAZ | INDUSTRIJA ONLINE VIJESTI| U HRVATSKOJ}

\section{Paško Bilić :: Jaka Primorac}

SAŽETAK Internetsko oglašavanje utječe na brojne promjene u proizvodnji, distribuciji i potrošnji komunikacije. Oslanjajući se na kritičku političku ekonomiju medija i komunikacije, u ovom radu nudimo podatke o ambivalentnom utjecaju koji podacima pokretana oglašavačka dinamika vrši na industriju vijesti i navike medijskih publika. Promatramo takozvani digitalni oglašavački jaz odnosno razliku između ukupne veličine tržišta internetskog oglašavanja i ukupnih prihoda tvrtki koje proizvode digitalne vijesti. Digitalni su posrednici poput Googlea i Facebooka konačna odredišta za većinu ulaganja u internetsko oglašavanje u Europi i Hrvatskoj. Višestrano tržište internetskog oglašavanja stvara plodno tlo za proizvodnju upitnog novinarskog sadržaja kojemu se ne može vjerovati. Digitalni oglašavački jaz primjer je tržišnog neuspjeha jer tržište ne uspijeva učinkovito distribuirati javne informacije. Tvrdimo da se povjerenje u samo-regulirajuću sposobnost internetskog tržišta treba preispitati u europskim i nacionalnim medijskim politikama.

KLJUČNE RIJEČI

INTERNETSKO OGLAŠAVANJE, DIGITALNI POSREDNICI, INDUSTRIJA VIJESTI, TRŽIŠNI NEUSPJEH, NEUSPJEH JAVNIH POLITIKA, JAVNA DOBRA, NOVINARSTVO

Bilješka o autorima

Paško Bilić :: Institut za razvoj i međunarodne odnose, Odjel za kulturu i komunikacije, Zagreb, Hrvatska :: pasko@irmo.hr

Jaka Primorac :: Institut za razvoj i međunarodne odnose, Odjel za kulturu i komunikacije, Zagreb, Hrvatska :: jaka@irmo.hr 